\title{
ОБЕСПЕЧЕНИЕ УСТОЙЧИВОСТИ ГОРНЫХ ВЫРАБОТОК В УСЛОВИЯХ СТРОЯЩИХСЯ КАЛИЙНЫХ РУДНИКОВ
}

\author{
И.А. МОРОЗОВ \\ Горный институт УрО РАН, г. Пермь
}

\begin{abstract}
Аннотация: В работе представлены и проанализированы основные факторы, определяющие устойчивость горных выработок в условиях Гремячинского рудника. Сформулированы основные подходы к оценке устойчивости горных выработок в условиях вновь разрабатываемого месторождения. Экспериментально подтверждена возможность применения метода объемного многоступенчатого нагружения для определения прочностных и деформационных характеристик соляных пород. Это позволяет снизить необходимый для лабораторных исследований объем породного материала, что особенно актуально при проектировании горных выработок в условиях малоизученных месторождений.

Ключевые слова: Соляные породы; Горные породы; Прочность пород; Устойчивость выработок
\end{abstract}

\section{Введение}

Российская Федерация - один из ведущих поставщиков калийных удобрений на мировой рынок. Сегодня на территории страны осваивается крупнейшее Верхнекамское калийномагниевое месторождение (ВКМКС), идет строительство Гремячинского рудника на вновь разрабатываемом Гремячинском месторождении (Волгоградская область).

Основной сложностью при проектировании и строительстве горнодобывающих предприятий на вводимых в эксплуатацию месторождениях является малая изученность последних. При этом уже на этапе проектирования необходимо определять оптимальный комплекс мероприятий, направленных на поддержание горных выработок в устойчивом состоянии. Основными проблемами, с которыми приходится сталкиваться, являются:

- недостаток сведений о геологическом строении месторождения;

- малая изученность физико-механических свойств пород.

Отсутствие опыта разработки вводимого в эксплуатацию месторождения также создает определенные сложности для горнодобывающего предприятия, что связано с необходимостью разработки методической базы по проектированию, строительству и поддержанию горных выработок в устойчивом состоянии.

Целью работы является исследование условий проведения горных выработок в соляных породах Гремячинского рудника, разработка методики определения прочностных и деформационных характеристик соляных пород в лабораторных условиях по минимальному объему породного материала.

\section{Условия проведения горных выработок в соляных породах \\ Гремячинского месторождения}

Основной особенностью разработки месторождения, осложняющей поддержание горных выработок в устойчивом состоянии, является глубина залегания промышленного сильвинитового пласта, которая составляет 1100-1300 м. Относительно невысокая прочность на одноосное сжатие каменной соли и сильвинита (не более 30-40 МПа [1]) предполагает интенсивное деформирование приконтурных пород сразу после проходки выработок с быстрым переходом в запредельное состояние.

Вблизи кровли сильвинитового пласта залегает мощная толща ангидрит-доломитовых пород с сильно изменчивыми физико-механическими свойствами и малоизученной трещиноватостью [2]. Наличие в кровле ангидрит-доломитовых пород может оказывать как положительное, так и отрицательное влияние на устойчивость горных выработок, пройденных в соляных породах. Несклонность ангидрит-доломитов к деформациям ползучести предполагает возникновение повышенных напряжений по контакту с соляными породами. Обнажение в кровле трещиноватых ангидрит-доломитов может приводить к вывалам отдельных породных блоков. При этом нали- 
чие высокопрочных нетрищиноватых ангидрит-доломитовых пород может повысить устойчивость выработок в соляных породах. Несмотря на это, по данным исследований [3], проведенных в схожих горно-геологических условиях, рекомендуется оставлять защитный слой каменной соли (сильвинита) между кровлей выработки и ангидрит-доломитовыми породами.

Еще одной особенностью разработки месторождения является наличие вблизи почвы промышленного сильвинитового пласта слабых карналлитовых пород [2], Прочность карналлитовых пород не превосходит 15 МПа, что предполагает их интенсивное деформирование, приводящее к пучению почвы выработки [4].

На сегодняшний день для обоснования проектных решений по проведению и поддержанию горных выработок в устойчивом состоянии следует использовать СП 91.13330.2012 «СНиП II-94-80. Подземные горные выработки. Актуализированная редакция». Устойчивость горной выработки определяется следующими горногеологическими и горнотехническими факторами [5]:

- глубиной расположения;

- формой и размерами поперечного сечения горной выработки;

- геологическим строением пород в пределах зоны возможного разрушения приконтурных пород;

- прочностными показателями приконтурных пород;

- расположением выработки относительно слабых слоев и прослоев;

- изрезанностью массива расположенными вблизи параллельными, горизонтальными или наклонными выработками и их сопряжениями.

Определение способов охраны и крепления горных выработок на этапе проектирования выполняется в зависимости от категории устойчивости приконтурных пород. Категория устойчивости по СП 91.13330.2012 определяется в зависимости от величины расчетных смещений контура незакрепленной выработки за весь срок ее эксплуатации без крепи. В общем случае расчетные смещения являются функцией вышеуказанных факторов, вид которой подлежит уточнению на этапе строительства, эксплуатации капитальных и подготовительных выработок. При определении расчетных смещений особо важное значение имеют физико-механические характеристики пород. В случае ввода в эксплуатацию нового месторождения наиболее остро стоит проблема, связанная с недостатком породного материала для проведения лабораторных исследований по определению свойств горных пород. Частично решить эту задачу позволяет специально адоптированный для соляных пород метод объемного многоступенчатого нагружения породных образцов.

\section{Метод объемного многоступенчатого нагружения}

\section{соляных породных образцов в лабораторных условиях}

Суть метода заключается в том, что образец испытывается при постоянном боковом давлении с постепенным увеличением осевой нагрузки (схема Кармана). В определенный момент происходит увеличение бокового давления до следующей ступени с последующим ростом осевой нагрузки. Таким образом, один образец может подвергаться нескольким ступеням нагружения, что существенно экономит необходимый объем породного материала. Впервые наиболее подробное исследование возможности применения указанного метода для определения физикомеханических свойств горных пород было представлено в работе [6]. При этом в литературе практически отсутствуют исследования применимости метода к соляным породам.

Для исследования возможности применения метода объемного многоступенчатого нагружения к соляным породам было изготовлено 26 образцов из сильвинита ВКМКС. Эксперименты выполнялись при следующих уровнях бокового давления: 2 МПа, 4 МПа, 8 МПа. Часть образцов была испытана в режиме стандартного (одноступенчатого) объемного нагружения, а другая часть - по многоступенчатой схеме. Характерная диаграмма деформирования образца сильвинита при объемном многоступенчатом нагружении представлена на рис. 1. 


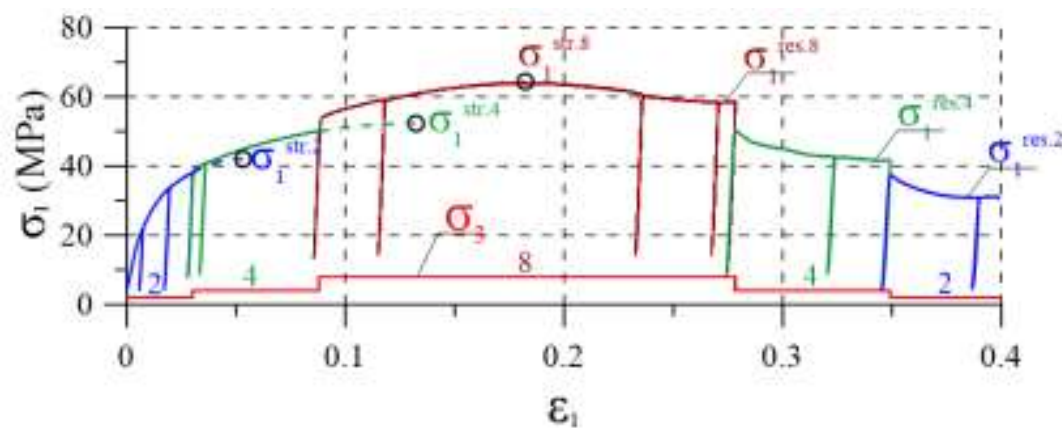

Рис. 1. Характерная диаграмма деформирования $\left(\sigma_{1}-\varepsilon_{1}\right)$ образца сильвинита при объемном многоступенчатом нагружении:

$\sigma_{1}{ }^{\text {str2 }}, \sigma_{1}{ }^{\text {str4 }}, \sigma_{1}{ }^{\text {str8 }}-$ предел прочности при боковом давлении $\sigma_{2}=\sigma_{3}=2$ МПа, 4 МПа, 8 МПа, соответственно; $\sigma_{1}{ }^{\text {res.2 }}, \sigma_{1}{ }^{\text {res.4 }}, \sigma_{1}{ }^{\text {res.8 }}$ - остаточная прочность при $\sigma_{2}=\sigma_{3}=2 \mathrm{MПа,} 4$ МПа, 8 МПа, соответственно

Для исследования изменения деформационных (упругих) характеристик образцов в процессе нагружения в зависимости от типа испытания и уровня бокового давления все образцы в ходе эксперимента подвергались серии разгрузок с последующим нагружением. По линейной части разгрузочной ветви диаграммы деформирования определялся модуль упругости. Диаграмма, отражающая изменение модуля упругости (Е, ГПа) образцов сильвинита в зависимости от типа испытания, стадии деформирования $\left(\sigma_{1} / \sigma_{\text {str. }}\right)$, уровня бокового давления $\left(\sigma_{2}\right.$ $\left.=\sigma_{3}\right)$, представлена на рис. 2. На рис. 2: «Pre-Peak»- область, соответствующая допредельной стадии деформирования; «Post-Peak» - область, соответствующая запредельной стадии деформирования; «Residual» - область, соответствующая деформированию на стадии остаточной прочности. На диаграмме сплошными линиями представлены аппроксимации результатов одноступенчатых испытаний, пунктирными (субгоризонтальными) - многоступенчатых. Субвертикальной красной пунктирной линией схематически отделяется область деформирования на стадии остаточной прочности.

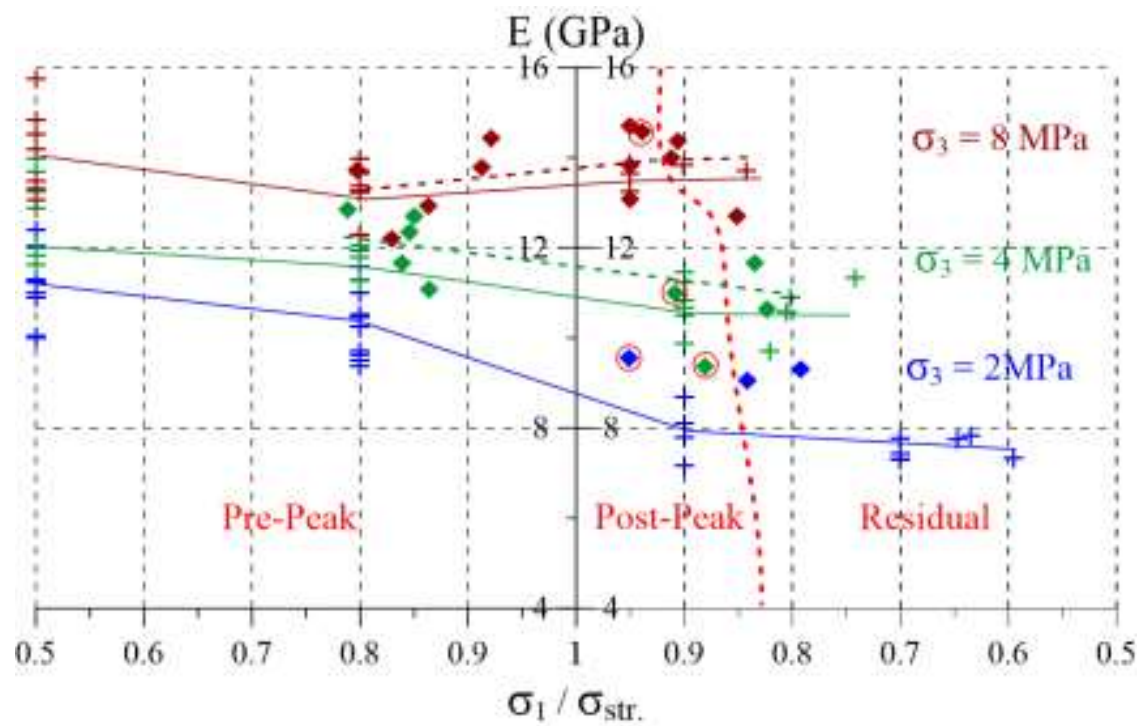

Рис. 2. Диаграмма, отражающая изменение модуля упругости образцов сильвинита в зависимости от типа испытания, стадии деформирования, уровня бокового давления

В ходе сопоставительных исследований методов объемного одноступенчатого и многоступенчатого нагружения образцов сильвинита удалось установить, что метод объемного многоступенчатого нагружения может быть использован для определения физико-механических свойств соляных пород в лабораторных условиях. Исследования показали, что погрешность определения прочности сильвинита не превосходит 10\%, остаточной прочности - $20 \%$. 


\title{
Заключение
}

Результатами проделанной работы являются:

- установлены и проанализированы основные факторы, влияющие на устойчивость выработок в соляных породах Гремячинского рудника;

- сформулированы общие положения, которых необходимо придерживаться при оценке устойчивости выработок в соляных породах Гремячинского рудника;

- экспериментально подтверждена возможность применения метода объемного многоступенчатого нагружения для определения прочностных и деформационных характеристик соляных пород, что позволяет существенно снизить необходимый объем породного материала.

\section{БИБЛИОГРАФИЧЕСКИЙ СПИСОК}

1. Боликов В.Е., Константинова С.А. Прогноз и обеспечение устойчивости капитальных горных выработок. - Екатеринбург: УрО РАН, 2003. - 374 с.

2. Морозов И.А. Формирование общих подходов повышения устойчивости капитальных горных выработок в условиях глубоких калийных рудников // Проблемы разработки месторождений углеводородных и рудных полезных ископаемых. - 2018. - № 1. - С. 351-353.

3. Константинова С.А., Крамсков Н.П., Соловьев В.А. Некоторые проблемы механики горных пород применительно к отработке алмазных месторождений Якутии. - Новосибирск: Наука, 2011. - 223 с.

4. Заславский Ю.З., Зорин А.Н., Черняк И.Л. Расчеты параметров крепи выработок глубоких шахт. Киев: Техника, 1972. - 156 с.

5. Константинова С.А., Соловьев В.А., Секунцов А.И., Аптуков В.Н. Оценка категорий устойчивости соляных и соленосных пород вокруг горных выработок в проектных решениях для строящихся рудников // Известия вузов. Горный журнал. - 2012. - № 3 - С. 70-73.

6. Kim, M., Ko, H. Multistage Triaxial Testing of Rocks // Geotechnical Testing Journal. - 1979. - V. 2, № 2. P. 98-105. doi: 10.1520/GTJ10435J.

\section{ГЕОФИЗИЧЕСКИЕ МЕТОДЫ ИЗУЧЕНИЯ НЕДР}

DOI: $10.7242 /$ echo.2019.2.12

\section{ИСПОЛЬЗОВАНИЕ СЕЙСМИЧЕСКИХ АТРИБУТОВ ДЛЯ ИЗУЧЕНИЯ СВОЙСТВ ПОРОД ВЕРХНЕЙ ЧАСТИ РАЗРЕЗА}

\author{
И.Ю. ГЕРАСИМОВА \\ Горный институт УрО РАН, г. Пермь
}

\begin{abstract}
Аннотация: Анализ сейсмических атрибутов, позволяющий выявлять свойства, состояние, взаимосвязи и особенности геологических образований, в настоящее время широко используются при комплексном изучении залежей углеводородов. Представлены результаты динамической интерпретации, проведенной для изучения особенностей строения приповерхностной части разреза и локализации ослабленных зон в приповерхностном интервале пород для объекта с негативным геомехническим прогнозом.

Ключевые слова: Верхнекамское месторождение калийных и магниевых солей, малоглубинная 3Dсейсморазведка, сейсмические атрибуты, ослабленная зона.
\end{abstract}

Сейсмические атрибуты широко используются при комплексном изучении залежей углеводородов, и, являясь неотъемлемой частью процесса сейсмической интерпретации, атрибутный анализ позволяет извлекать из сейсмических данных дополнительную информацию. Современные методы цифровой регистрации и визуализации позволяют оперировать десятками атрибутов, что проявляется в многогранности динамической интерпретации как при выборе собственно параметров анализа, так и в спектре решаемых задач.

В общем случае, на трансформацию сейсмического отклика влияют любые колебания скорости или плотности в массиве пород, обусловленные изменениями литологического и/или минерального состава, пористости, типа и степени насыщения пор и др. Анализ сейсмических атри- 